\title{
Para-oesophageal and parahiatal hernias in an Asian acute care tertiary hospital: an underappreciated surgical condition
}

Ye Xin $\underline{K o h}^{1}$, MBBS, MRCS, Lester Wei Lin $\underline{O n g}^{1}$, MBBS, MRCS, June Lee ${ }^{1}$, MBBS, FRCS, Andrew Siang Yih $\underline{\text { Wong }}^{1}$, MBBS, FRCS

INTRODUCTION The prevalence of hiatal hernias and para-oesophageal hernias (PEHs) is lower in Asian populations than in Western populations. Progressive herniation can result in giant PEHs, which are associated with significant morbidity. This article presents the experience of an Asian acute care tertiary hospital in the management of giant PEH and parahiatal hernia. METHODS Surgical records dated between January 2003 and January 2013 from the Department of Surgery, Changi General Hospital, Singapore, were retrospectively reviewed.

RESULTS Ten patients underwent surgical repair for giant PEH or parahiatal hernia during the study period. Open surgery was performed for four patients with giant PEH who presented emergently, while elective laparoscopic repair was performed for six patients with either giant PEH or parahiatal hernia (which were preoperatively diagnosed as PEH). Anterior $180^{\circ}$ partial fundoplication was performed in eight patients, and mesh reinforcement was used in six patients. The electively repaired patients had minimal or no symptoms during presentation. Gastric volvulus was observed in five patients. There were no cases of mortality. The median follow-up duration was 16.3 months. There were no cases of mesh erosion, complaints of dysphagia or recurrence of PEH in all patients.

CONCLUSION Giant PEH and parahiatal hernia are underdiagnosed in Asia. Most patients with giant PEH or parahiatal hernia are asymptomatic; they often present emergently or are incidentally diagnosed. Although surgical outcomes are favourable even with a delayed diagnosis, there should be greater emphasis on early diagnosis and elective repair of these hernias.

Keywords: gastric volvulus, laparoscopy, para-oesophageal hernia, parahiatal hernia

\section{INTRODUCTION}

Asian populations have a lower prevalence of hiatal hernia $(\mathrm{HH})$ compared to Western populations. Population studies conducted in Sweden, Italy and China have shown a $\mathrm{HH}$ prevalence of $23.9 \%, 43.0 \%$ and $0.7 \%$, respectively. ${ }^{(1-4)}$ It is estimated that $5 \%$ of all $\mathrm{HHs}$ are para-oesophageal hernias (PEHs). ${ }^{(5)}$

Large PEHs with herniation of more than half of the stomach into the chest are termed giant PEHs ${ }^{(6)}$ Giant PEHs are associated with significant morbidity due to the increased risk of volvulus, gangrene, perforation and massive bleeding. ${ }^{(7)}$ To avoid serious complications, elective repair has been advocated for giant PEHs and demonstrated favourable mortality rates $(<1 \%)$ in a large case series involving a Western population. ${ }^{(8)}$ However, no similar studies or randomised trials examining the utility of elective repair for giant PEHs have been conducted in Asian centres. This may be due to the low incidence of the disease. Thus, Asian literature reporting on this disease is limited to isolated case reports. ${ }^{(9,10)}$

Parahiatal hernia is an even rarer entity. It is often preoperatively misdiagnosed as $\mathrm{PEH}$, as they have similar radiological findings. To date, only four cases of parahiatal hernia have been reported in Western centres and 11 cases in Asian centres. ${ }^{(11-17)}$ The reported incidence is low, accounting for only $1.6 \%$ and $0.35 \%$ of all preoperatively diagnosed PEHs in Western and Asian centres, respectively. ${ }^{(11,13)}$ Since the management of parahiatal hernia differs from that of $\mathrm{PEH}$, it is important that these two entities are effectively differentiated.

The aim of this study was to present the experience of an Asian acute care tertiary hospital in the management of giant PEHs and parahiatal hernias, in order to enhance the understanding of these rare but important conditions. The presentation, diagnosis, and approach to emergency and elective surgical treatment of PEHs and parahiatal hernias are reviewed and discussed.

\section{METHODS}

We performed a retrospective review of endoscopic and surgical records from the Upper Gastrointestinal Surgery Service, Department of Surgery, Changi General Hospital, Singapore. Only records that were dated between January 2003 and January 2013 were reviewed.

PEHs, also known as Type II HHs, occur when a localised defect in the phreno-oesophageal membrane allows upward migration of the gastric fundus through the oesophageal hiatus while the gastro-oesophageal junction (GEJ) remains fixed to the preaortic fascia and median arcuate ligament. Progressive enlargement of the oesophageal hiatus and hernia sac may result in Type III HH. The different types of $\mathrm{HH}$ are presented in Table I. ${ }^{(18)} \mathrm{A}$ giant $\mathrm{PEH}$ is one that has more than $50 \%$ of the stomach herniating through the hiatus into the thoracic cavity. ${ }^{(6)}$ Other organs that have been found in these hernia sacs include the colon, spleen, pancreas 
Table I. Types of hiatal hernia.

\begin{tabular}{|c|c|c|c|}
\hline Name & Type & Description & Major significance \\
\hline Hiatal hernia & 1 & $\begin{array}{l}\text { Sliding hiatal hernia; widening of the muscular hiatal tunnel and } \\
\text { circumferential laxity of the phreno-oesophageal membrane (which } \\
\text { remains intact); portion of gastric cardia herniates into thoracic cavity }\end{array}$ & Gastro-oesophageal reflux disease \\
\hline \multirow[t]{3}{*}{$\begin{array}{l}\text { Para-oesophageal } \\
\text { hernia }\end{array}$} & II & $\begin{array}{l}\text { Rolling hiatal hernia; a localised defect in the phreno-oesophageal } \\
\text { membrane, but the gastro-oesophageal junction remains fixed to the } \\
\text { preaortic fascia and median arcuate ligament; gastric fundus serves as } \\
\text { the lead point of herniation }\end{array}$ & $\begin{array}{l}\text { Mechanical complications: gastric } \\
\text { volvulus; incarceration; obstruction; } \\
\text { ischaemia; perforation }\end{array}$ \\
\hline & III & Elements of both Type I and Type II HH & \\
\hline & IV & $\begin{array}{l}\text { Large defect in the phreno-oesophageal membrane; other organs, such } \\
\text { as the colon, spleen, pancreas and small bowel, enter the hernia sac }\end{array}$ & \\
\hline
\end{tabular}

and small bowel. Parahiatal hernia is defined as herniation of the abdominal viscera through a muscular defect in the diaphragm lateral to, but distinct from, an intact oesophageal hiatus (Fig. 1).

$\mathrm{PEH}$ was diagnosed using computed tomography (CT) of the chest and abdomen in all but one case. Preoperatively, no further investigation was performed if the patient had symptoms of gastric outlet obstruction, small bowel obstruction or respiratory compromise, and required emergency surgery. Patients who were asymptomatic or had only mild pain that could be controlled using analgesics were managed electively; they underwent further preoperative evaluation with upper endoscopy and contrast studies of the upper gastrointestinal tract. The choice of surgical access was determined according to each patient's presentation. Open procedures were performed for patients who presented emergently with obstructive symptoms or respiratory compromise, while laparoscopic surgeries were performed for elective cases where the patients were asymptomatic or had minor symptoms.

The open approach utilised an upper midline incision. Dissection of the diaphragmatic hiatus was performed to expose the crura, followed by reduction of the herniated contents into the abdominal cavity. The hernia sac was then dissected off the pleura and the thoracic oesophagus was mobilised to ensure an adequate length of abdominal oesophagus, with the GEJ brought within the abdominal cavity. When indicated, posterior gastropexy and gastrostomy were performed for fixation of the stomach to the anterior abdominal wall to prevent recurrent herniation. A nonencircling biocompatible mesh was placed when the crura could not be repaired without tension. Anti-reflux procedures were not performed in the emergency setting.

All elective patients underwent laparoscopic repair. The French position was routinely used, with the surgeon standing between the patient's legs and an assistant standing on the patient's right. Two 5-mm and two 12-mm ports were placed in the upper abdomen for the working instruments. The left lateral segment of the liver was retracted using a Nathanson retractor for exposure of the diaphragmatic hiatus.

In cases of giant PEH, the gastrohepatic ligament at the level of the right crus was first dissected. This dissection was carried to the left side, over the anterior surface of the oesophagus and toward the gastrosplenic ligament. Attachments to the gastric fundus were divided, and the dissection was completed with the dissection of the retro-oesophageal space to expose the right and left crura. The contents of the hernia sac would then be reduced
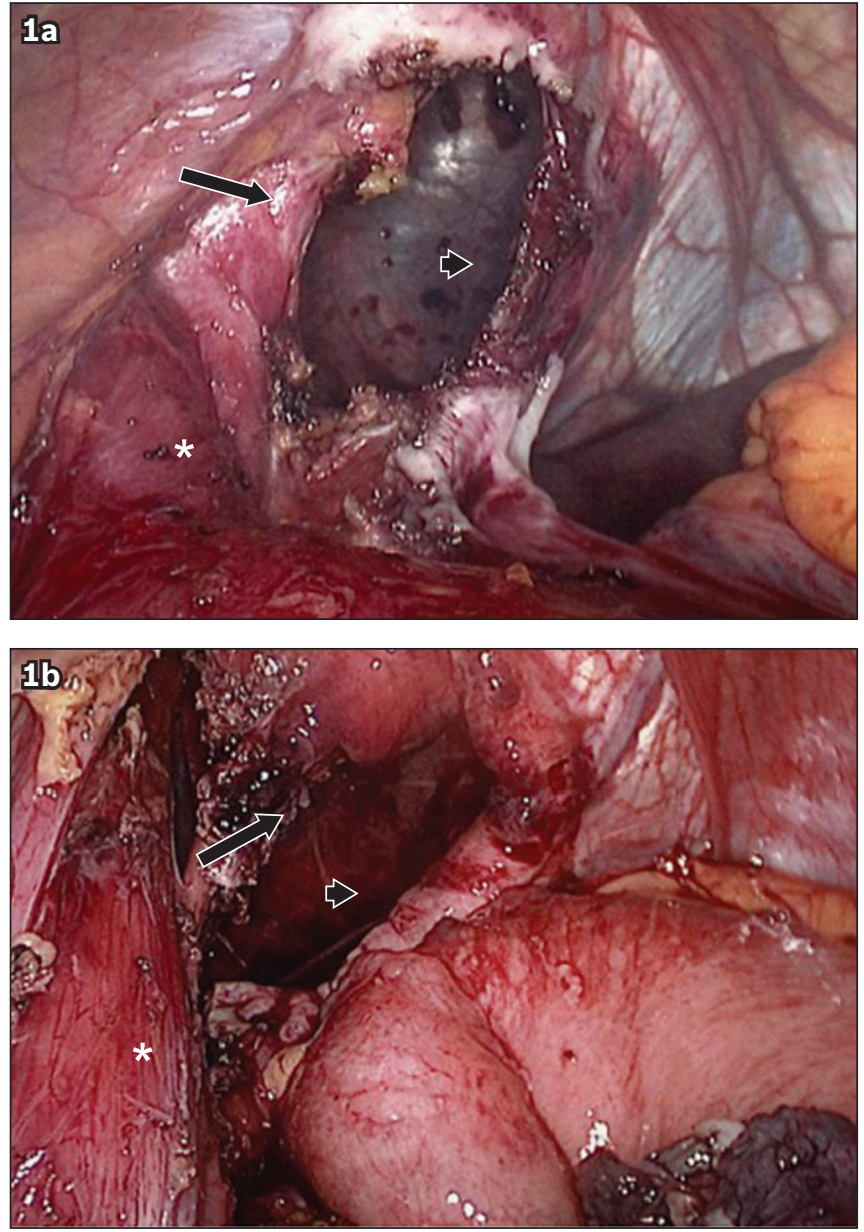

Fig. 1 Intraoperative photographs of (a) Patient A and (b) Patient B show parahiatal hernias (arrowheads) adjacent to the intact left diaphragmatic crura (arrows). The oesophagus is denoted by the asterisks $\left({ }^{*}\right)$.

into the abdomen. If present, the colon and small bowel were reduced before the stomach. The hernia sac was dissected off the pleura using a combination of blunt sweeping dissection and sharp dissection with a hook diathermy or harmonic scalpel aided by the pneumoperitoneum.

In all cases of giant PEH, the intrathoracic oesophagus was routinely mobilised up to the level of the inferior pulmonary vein to ensure that the intra-abdominal segment of the oesophagus was tension-free and did not retract into the thoracic cavity. Retraction of a Penrose drain or nylon tape looped around the GEJ was employed to aid this process. The diaphragmatic defect was closed without tension using interrupted sutures and mesh. 
Table II. Details of the patients who underwent emergency surgery $(n=4)$.

\begin{tabular}{|c|c|c|c|c|c|c|}
\hline $\begin{array}{l}\text { Age }(\mathrm{yr}) \text {, } \\
\text { gender, } \\
\text { BMI }\left(\mathrm{kg} / \mathrm{m}^{2}\right)\end{array}$ & $\begin{array}{l}\text { Previous } \\
\text { surgery }\end{array}$ & $\begin{array}{l}\text { Symptoms at } \\
\text { presentation }\end{array}$ & $\begin{array}{l}\text { Defect size and } \\
\text { contents }\end{array}$ & Management & Complication & $\begin{array}{l}\text { Postoperative } \\
\text { course }\end{array}$ \\
\hline $55, M, 25.6$ & $\begin{array}{l}\text { Fundoplication } \\
5 \text { yr prior to } \\
\text { presentation }\end{array}$ & $\begin{array}{l}\text { Gastric outlet } \\
\text { obstruction with } \\
\text { projectile vomiting } \\
\text { for } 2 \text { days }\end{array}$ & $\begin{array}{l}4 \mathrm{~cm} \times 4 \mathrm{~cm} ; 90 \% \\
\text { of stomach in } \\
\text { organoaxial volvulus, } \\
40 \mathrm{~cm} \text { of the small } \\
\text { bowel, transverse } \\
\text { colon and omentum }\end{array}$ & $\begin{array}{l}9 \mathrm{~cm} \times 9 \mathrm{~cm} \text { Parietex }{ }^{\mathrm{TM}} \\
\text { mesh bridge; posterior } \\
\text { gastropexy and anterior } \\
\text { gastrostomy }\end{array}$ & None & $\begin{array}{l}\text { POD 2: GF } \\
\text { POD 3: Liquid diet } \\
\text { POD 5: FM diet } \\
\text { POD 8: Discharged }\end{array}$ \\
\hline $76, F, 23.4$ & None & $\begin{array}{l}\text { Gastric outlet } \\
\text { obstruction with } \\
\text { projectile vomiting } \\
\text { for } 3 \text { days }\end{array}$ & $\begin{array}{l}\text { Size not specified; } \\
100 \% \text { of stomach in } \\
\text { organoaxial volvulus }\end{array}$ & $\begin{array}{l}\text { Posterior crural repair } \\
\text { reinforced with } \\
2 \mathrm{~cm} \times 4 \mathrm{~cm} \text { TiMESH}{ }^{\circledR} \\
\text { mesh implant; posterior } \\
\text { gastropexy and anterior } \\
\text { gastrostomy }\end{array}$ & $\begin{array}{l}\text { Superficial wound } \\
\text { infection }\end{array}$ & $\begin{array}{l}\text { POD 5: GF } \\
\text { POD 6: Liquid diet } \\
\text { POD 8: FM diet } \\
\text { POD 10: Discharged }\end{array}$ \\
\hline 75, M, 19.3 & None & $\begin{array}{l}\text { Small bowel } \\
\text { obstruction with } \\
\text { abdominal } \\
\text { distension and } \\
\text { vomiting for } 5 \text { days }\end{array}$ & $\begin{array}{l}\text { Size not specified; } \\
60 \% \text { of stomach, } \\
100 \mathrm{~cm} \text { of small } \\
\text { bowel, transverse } \\
\text { colon and omentum }\end{array}$ & $\begin{array}{l}\text { Posterior and anterior } \\
\text { crural repair }\end{array}$ & Left pneumothorax & $\begin{array}{l}\text { POD 4: GF } \\
\text { POD 4: Liquid diet } \\
\text { POD 6: FM diet } \\
\text { POD 12: Discharged }\end{array}$ \\
\hline
\end{tabular}

BMI: body mass index; F: female; FM: finely minced; GF: Gastrografin contrast study; M: male; POD: postoperative day

Additional sutures were placed in the diaphragm anterior to the oesophagus to prevent over-angulation. The fundus of the stomach was mobilised by dividing the short gastric vessels, and anterior $180^{\circ}$ fundoplication was routinely performed. Finally, the dissected hernia sac was interposed between the mesh and oesophagus to reduce the risk of mesh erosion.

For elective patients, a water-soluble contrast study was performed a day after surgery. If the study demonstrated a smooth flow of contrast across the hiatal repair and fundoplication, the patient was started on liquids. The patient's diet would then be gradually adjusted over a range of consistencies, as tolerated by the patient and guided by a dietician. Most patients were on a soft diet by postoperative day 5-7 and a normal diet 1-2 weeks after the initiation of the soft diet. Emergency patients usually had the contrast study performed a few days after surgery, when they were able to get out of bed. They were progressed to a normal diet in a similar manner as the elective patients.

All patients were seen a month after discharge to evaluate their progress. Thereafter, they were seen at six-month intervals. Water-soluble contrast swallow study was performed if there was suspicion of hernia recurrence. Water-soluble contrast swallow study or CT was also performed at six months and one year after surgery to exclude asymptomatic recurrence. All patients with mesh placement were examined using upper endoscopy at one year after surgery to exclude mesh erosion.

\section{RESULTS}

In our retrospective review, we identified 1,001 patients with an endoscopic diagnosis of hiatal hernia. Of these patients, eight had a diagnosis of giant $\mathrm{PEH}$ and two had a diagnosis of parahiatal hernia. These ten patients, whose median age was 54.4 (range 38.0-79.0) years, underwent surgical repair between January 2003 and January 2013. Six of them presented acutely - four required emergency surgery and two were managed conservatively before undergoing semi-elective surgery a week after presentation. The clinical presentation, intraoperative findings and postoperative outcomes of the four patients who underwent emergency surgery are presented in Table II.

All four emergency surgeries were performed via midline laparotomy. In two cases, complete reduction of the hernia contents was only possible after the constriction was widened via an incision in the crura. The small bowel and transverse colon were usually reduced before reduction of the stomach. Two of the four patients with symptoms of gastric outlet obstruction had constriction of the pylorus at the level of the diaphragmatic hiatus, due to complete or almost complete herniation of the stomach with associated organoaxial gastric volvulus. These two patients required posterior gastropexy and anterior gastrostomy to reduce the risk of recurrent herniation and gastric volvulus. Three of the four patients underwent mesh repair - one received mesh repair because the defect was too large to be closed primarily without tension and the mesh had to be used to bridge the defect, while the other two patients had mesh reinforcement of the primary posterior crural repair. As there was no gastric or bowel ischaemia, bowel resection was not necessary in these three cases.

Elective repair was carried out in the remaining six patients who had minor or no symptoms. The procedure of choice for such patients was laparoscopic repair. The presentation, type and size of hernia defects, management, and postoperative course of these six patients are presented in Table III. Although all six patients had $\geq 50 \%$ of the stomach volume herniated into 
Table III. Details of the patients who underwent elective surgery $(n=6)$.

\begin{tabular}{|c|c|c|c|c|c|c|}
\hline $\begin{array}{l}\text { Age }(\mathrm{yr}) \\
\text { gender, BMI } \\
\left(\mathrm{kg} / \mathrm{m}^{2}\right)\end{array}$ & $\begin{array}{l}\text { Symptoms at } \\
\text { presentation }\end{array}$ & $\begin{array}{l}\text { Symptom } \\
\text { duration }\end{array}$ & $\begin{array}{l}\text { Hernia defect } \\
\text { type and size }\end{array}$ & $\begin{array}{l}\text { Gastric } \\
\text { volvulus }\end{array}$ & Management & $\begin{array}{l}\text { Postoperative } \\
\text { course }\end{array}$ \\
\hline 40, F, 27.8 & $\begin{array}{l}\text { Epigastric pain, } \\
\text { anaemia }\end{array}$ & $4 \mathrm{yr}$ & $\begin{array}{l}\text { Parahiatal; } \\
5 \mathrm{~cm} \times 5 \mathrm{~cm}\end{array}$ & Mesenteroaxial & $\begin{array}{l}\text { Posterior crural repair using } 6 \\
\text { stitches; no fundoplication }\end{array}$ & $\begin{array}{l}\text { POD 1: Liquid diet } \\
\text { POD 2: FM diet } \\
\text { POD 2: Discharged }\end{array}$ \\
\hline $38, F, 21.0$ & $\begin{array}{l}\text { Asymptomatic, } \\
\text { incidental } C X R \\
\text { finding }\end{array}$ & 14 days & $\begin{array}{l}\text { PEH; size not } \\
\text { specified }\end{array}$ & None & $\begin{array}{l}\text { GORE-TEX }{ }^{\circledR} \text { mesh with ProTack }{ }^{\mathrm{TM}} \\
\text { fixation; no fundoplication }\end{array}$ & $\begin{array}{l}\text { POD 2: Liquid diet } \\
\text { POD 3: FM diet } \\
\text { POD 6: Discharged }\end{array}$ \\
\hline $51, F, 24.0$ & Epigastric pain & 4 days & $\begin{array}{l}\text { Parahiatal; } \\
3 \mathrm{~cm} \times 3 \mathrm{~cm}\end{array}$ & Mesenteroaxial & $\begin{array}{l}\text { Posterior crural repair using } 2 \\
\text { stitches; bridge with } 7 \mathrm{~cm} \times 7 \mathrm{~cm} \\
\text { Parietex }{ }^{\mathrm{TM}} \text { mesh; anterior } 180^{\circ} \\
\text { fundoplication }\end{array}$ & $\begin{array}{l}\text { POD 1: Liquid diet } \\
\text { POD 3: FM diet } \\
\text { POD 5: Discharged }\end{array}$ \\
\hline $65, F, 24.3$ & Epigastric pain & 14 days & $\begin{array}{l}\text { PEH; size not } \\
\text { specified }\end{array}$ & Organoaxial & $\begin{array}{l}\text { Posterior crural repair using } 2 \\
\text { posterior and } 2 \text { anterior stitches; } \\
\text { anterior } 180^{\circ} \text { fundoplication }\end{array}$ & $\begin{array}{l}\text { POD 2: Liquid diet } \\
\text { POD 4: FM diet } \\
\text { POD 9: Discharged }\end{array}$ \\
\hline $58, M, 31.5$ & $\begin{array}{l}\text { Asymptomatic } \\
\text { anaemia, incidental } \\
\text { OGD finding }\end{array}$ & $5 \mathrm{mth}$ & $\begin{array}{l}\text { PEH; size not } \\
\text { specified }\end{array}$ & None & $\begin{array}{l}\text { Posterior crural repair using } \\
3 \text { stitches; anterior } 180^{\circ} \\
\text { fundoplication }\end{array}$ & $\begin{array}{l}\text { POD 2: Liquid diet } \\
\text { POD 3: FM diet } \\
\text { POD 4: Discharged }\end{array}$ \\
\hline 79, F, 28.3 & $\begin{array}{l}\text { Asymptomatic, } \\
\text { incidental CXR } \\
\text { finding }\end{array}$ & $4 \mathrm{mth}$ & $\begin{array}{l}\text { PEH; size } \\
\text { not specified } \\
\text { (post-crural } \\
\text { repair: } \\
2.5 \mathrm{~cm} \times 2.5 \mathrm{~cm} \text { ) }\end{array}$ & None & $\begin{array}{l}\text { Posterior crural repair using } 6 \\
\text { stitches and } 1 \text { anterior stitch } \\
\text { reinforced with } 7 \mathrm{~cm} \times 7 \mathrm{~cm} \\
\text { TiMESH}^{\circledR} \text { mesh implant; anterior } \\
180^{\circ} \text { fundoplication }\end{array}$ & $\begin{array}{l}\text { POD 1: Liquid diet } \\
\text { POD 2: FM diet } \\
\text { POD 6: Discharged }\end{array}$ \\
\hline
\end{tabular}

BMI: body mass index; CXR: chest X-ray; F: female; FM: finely minced; M: male; OGD: oesophago-gastro-duodenoscopy; PEH: para-oesophageal hernia; POD: postoperative day

the thoracic cavity, only three of them had gastric volvulus. No other organs were found in their hernia sacs and none of them suffered from gastric ischaemia. Two of the six patients presented to the emergency department of our institution with epigastric pain, which improved with the administration of analgesics; they were discharged and scheduled for a gastrointestinal workup as an outpatient. One patient had chronic epigastric pain for four years before consultation. These three patients with minor symptoms had associated gastric volvulus, while the remaining three asymptomatic patients did not. None of the six patients had gastro-oesophageal or Cameron's ulcer on upper endoscopy evaluation.

Among the six patients who underwent elective surgery, four had anterior $180^{\circ}$ fundoplication and three had hiatal plasty with prosthetic mesh. Of the three patients who had hiatal plasty with prosthetic mesh, two had defects that could not be closed primarily without tension and meshes were used to bridge the defects, while one had a tear in the diaphragm after primary repair, which was reinforced with a TiMESH ${ }^{\circledR}$ mesh implant.

Two cases of parahiatal hernias were incidentally discovered during dissection of the hernia sac. In both cases, the hernia defect was found lateral to the left crus of an intact GEJ. In one case, the 3-cm hernia defect could not be approximated without excessive tension due to a fibrotic ring around the defect, and thus, a biocompatible mesh repair was employed. In the other case, the $5-\mathrm{cm}$ hernia defect was repaired with primary suture using interrupted polypropylene.

The median time to a liquid diet was 1.5 days among patients who had elective surgery, while the time to a finely minced diet and time to discharge were three and five days, respectively. The recovery progress of the six patients who underwent elective surgery (i.e. laparoscopic repair) was faster than that of the four patients who underwent emergency surgery (i.e. open surgery performed via a midline laparotomy); we did not test the statistical significance of this finding, as the numbers of the two groups were small.

For all ten patients, the mean duration of follow-up was 16.3 (range 4.0-43.0) months. Although three of the four patients who underwent emergency surgery had minor complications, none required a repeat surgery and there were no deaths. There were no cases of mesh erosion, dysphagia, recurrence of $\mathrm{PEH}$ and gastric volvulus among both the patients who underwent emergency surgery and those who underwent elective surgery. At follow-up, all patients reported minimal or no symptoms.

\section{DISCUSSION}

Although HHs, gastro-oesophageal reflux disease (GERD) and oesophagitis are frequently observed to coexist, the exact nature of their relationship with one another is not completely understood. ${ }^{(19,20)}$ In a large-scale study conducted in Singapore, which involved 11,934 symptomatic patients who underwent upper endoscopy, the prevalence of oesophagitis was only $3.3 \% .^{(21)}$ Other studies that were conducted in Korea, Hong Kong and Taiwan also reported a low prevalence of GERD $(5 \%-17 \%) .^{(22-24)}$ Based on these numbers, we can expect a similarly low prevalence rate of $\mathrm{HH}$ in Asian populations. Kang and Ho provided evidence for this in their study, which showed that the prevalence of $\mathrm{HH}$ among dyspeptic patients in Singapore was only $4 \%(n=7 / 173)$ as compared to $23.6 \%(n=50 / 212)$ among dyspeptic patients in England. ${ }^{(25)}$ It has been hypothesised that the differences in predisposing factors (such as body mass index, oesophageal sphincter pressure and dietary habits) between 
Asian and Western populations may account for the difference in the prevalence of oesophagitis and $\mathrm{HH}^{(26)}$ However, little evidence exists to support this hypothesis or to account for the significant differences in prevalence of oesophagitis and $\mathrm{HH}$ in Asian and Western populations.

Only approximately $5 \%$ of all $\mathrm{HHs}$ are $\mathrm{PEHs}^{\left({ }^{(5)}\right.}$ this could account for the paucity of PEH cases seen in Asian populations. Furthermore, Asian patients with $\mathrm{PEH}$ may have minimal or no symptoms, or nonspecific symptoms (ranging from mild nausea and abdominal distension to acute presentation with obstructive symptoms and dyspnoea), which make early and accurate diagnosis challenging, especially in an emergency situation. ${ }^{(9)}$ The difficulty in accurately diagnosing $\mathrm{PEH}$ could result in the underreporting of cases in our Asian population, as patients with PEH may not be identified because they are asymptomatic, or they may be misdiagnosed as having other conditions. Thus, in the Asian context, clinicians need to have a high index of suspicion when patients present with acute upper gastrointestinal tract symptoms.

Mortality after emergency surgery for PEH may be as high as $40 \%$ (mean $17 \%$ ). ${ }^{(27)}$ Acute gastric volvulus, which is frequently associated with $\mathrm{PEH}$, has a mortality rate of $30 \%-50 \%$, with major sequelae such as gastric necrosis, perforation and hypovolaemic shock. ${ }^{(28)}$ In the present study, although five of the ten patients with $\mathrm{PEH}$ or parahiatal hernia had associated gastric volvulus, there were no mortalities. Two of these five patients successfully underwent open repair, while the remaining three patients underwent laparoscopic repair with equally favourable outcomes. Although the numbers are small, this finding suggests that laparoscopic repair may be a feasible option for the treatment of PEH with associated gastric volvulus; this has been reported in other studies. ${ }^{(29,30)}$ A more recent study by Teague et al also showed good results with no mortality in all of their 36 patients, five of which had chronic volvulus that were treated conservatively. ${ }^{(31)}$ It is worth noting that, even though $\mathrm{PEH}$ is a rare condition in Asian populations and experience with $\mathrm{PEH}$ is limited, there were no mortalities in the present study.

Although laparoscopic repair is gaining popularity, the open approach may be safer for patients who present acutely with obstructive symptoms, haemodynamic instability or respiratory instability, or if gastric ischaemia is suspected. This is because open surgery allows for easier gastric decompression and faster reduction of the herniated stomach as compared to laparoscopic surgery. In the present study, laparoscopic repair was reserved for stable, minimally symptomatic or asymptomatic patients who were scheduled for elective surgery.

Repair of the crura and reconstitution of the hiatus is the most important part of the operation to prevent recurrence. In our hospital, primary repair of the crura posterior to the oesophagus with interrupted polypropylene sutures is preferred, as the diaphragmatic crura are stronger posteriorly. However, excessive placement of the sutures posteriorly can lead to over-angulation of the GEJ and cause postoperative dysphagia. ${ }^{(32)}$ As such, some sutures had to be placed in the crura anterior to the oesophagus to prevent over-angulation of the GEJ.
In our hospital, a prosthetic mesh is not used if primary repair can be performed without tension. An exception is made if parts of the patient's diaphragm are thinned out and may subsequently tear, leading to failure of therapy; in such cases, the mesh is used as a reinforcement of the primary repair. In cases where the hiatal defect cannot be approximated without tension, a prosthetic mesh is used as a bridge to patch the enlarged hiatus without approximating the crura while allowing the passage of the oesophagus. ${ }^{(33)}$ Proponents of the mesh cite lower hernia recurrence rates, while opponents cite the occurrence of complications such as dysphagia, oesophageal stenosis and erosion of the mesh into the oesophagus. ${ }^{(34,35)}$ In the present study, the dissected hernia sac was routinely used as an interposition between the mesh and oesophagus to reduce the risk of erosion; there were no cases of recurrence, mesh erosion or dysphagia among the patients who received mesh implants.

As demonstrated in the present study, parahiatal hernia is a possible alternate diagnosis for preoperatively diagnosed PEH. In a study conducted by Scheidler et al in a single Western centre, the incidence of parahiatal hernia in their cohort of laparoscopically treated HHs was $0.2 \%$ (2/917). ${ }^{(11)}$ Similarly, Palanivelu et al reported a low incidence of parahiatal hernia $(0.35 \%, 4 / 1,127)$ in their cohort of $\mathrm{HH}$ patients who were laparoscopically treated in a single Asian centre. ${ }^{(13)}$ The unusually high proportion of parahiatal hernias in our hospital $(20 \%, 2 / 10)$ might either indicate an underreporting of $\mathrm{HHs}$ (thereby leading to the smaller overall number of $\mathrm{HH}$ s being treated), or suggest that parahiatal hernia is an underappreciated condition that should be actively excluded in the differential diagnosis during surgical exploration of all PEHs.

A comparison of parahiatal hernia cases is shown in

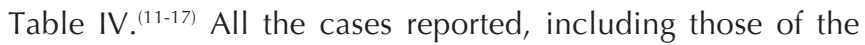
present study, were left parahiatal hernias, suggesting that left parahiatal hernias are more common than right parahiatal hernias. Therefore, it is important to pay attention when dissecting in the region to the left of the diaphragmatic crura during surgery to treat an apparent $\mathrm{PEH}$, so that the possibility of a parahiatal hernia can be excluded. This also ensures that transection of the left crural fibres during routine dissection can be prevented. In cases where parahiatal hernias are suspected immediately upon laparoscopy, focused dissection should be performed at the left crus; the right crus may be left alone, as unnecessary dissection might disrupt an otherwise normal hiatus. Fundoplication is also typically not required unless the patient has symptomatic reflux, ${ }^{(16)}$ as was the case for one of our ten patients. Hence, a history of GERD symptoms should be elicited in all patients with $\mathrm{PEH}$ prior to surgery. The other principles for the management of PEH also apply to the management of parahiatal hernias.

In the present study, all ten patients reported minimal or no symptoms during follow-up. Investigations were performed routinely to review the effects of the mesh implant and to exclude mesh erosion. Although it is known that anatomical recurrences can occur in up to $42 \%$ of laparoscopically repaired $\mathrm{HH}$ cases, these patients are rarely symptomatic and very few require repeat surgery. ${ }^{(36,37)}$ There were no patients with symptomatic recurrence in our study. 
Table IV. Comparison of the clinical characteristics and surgical treatment of parahiatal hernias.

\begin{tabular}{|c|c|c|c|c|}
\hline Author, year, country & $\begin{array}{l}\text { Age (yr), gender, } \\
\text { symptom }\end{array}$ & $\begin{array}{l}\text { Characteristics of parahiatal } \\
\text { hernia(s) }\end{array}$ & Treatment & Postoperative recovery \\
\hline $\begin{array}{l}\text { Demmy et al, }{ }^{(16)} 1994, \\
\text { USA }\end{array}$ & $\begin{array}{l}48, F, \text { abdominal } \\
\text { pain and shortness } \\
\text { of breath }\end{array}$ & $\begin{array}{l}1 \text { primary parahiatal hernia located } \\
\text { at the left crus; defect size: } 2 \mathrm{~cm} \text {; } \\
\text { volvulus not stated but gastric } \\
\text { necrosis noted }\end{array}$ & $\begin{array}{l}\text { Elective surgery; } \\
\text { exploratory left } \\
\text { thoracotomy, pleura } \\
\text { decortication and } \\
\text { drainage; gastric } \\
\text { resection }\end{array}$ & $\begin{array}{l}\text { Discharged on POD } 42 ; \text { no } \\
\text { other details provided }\end{array}$ \\
\hline $\begin{array}{l}\text { Rodefeld et al, }{ }^{(17)} \\
\text { 1997, USA }\end{array}$ & $63, F$, reflux & $\begin{array}{l}1 \text { primary parahiatal hernia located } \\
\text { at the left crus; defect size: } \\
5 \mathrm{~cm} \text { diameter; associated with } \\
\text { mesenteroaxial volvulus }\end{array}$ & $\begin{array}{l}\text { Elective surgery; } \\
\text { laparoscopic repair; } \\
\text { primary closure; Nissen } \\
\text { fundoplication }\end{array}$ & $\begin{array}{l}\text { Liquid diet on POD 1; soft } \\
\text { diet on POD } 3 \text {; no reflux } \\
\text { detected on barium swallow } \\
\text { at } 2 \text { mth; asymptomatic } \\
\text { throughout } 15 \text { mth of } \\
\text { follow-up }\end{array}$ \\
\hline \multirow[t]{2}{*}{$\begin{array}{l}\text { Scheidler et al, }{ }^{(11)} \\
2002, \text { USA }\end{array}$} & $\begin{array}{l}68, \mathrm{~F} \text {, reflux on } \\
\text { 24-hr pH monitoring }\end{array}$ & $\begin{array}{l}1 \text { primary parahiatal hernia located } \\
\text { at the left crus; defect size not } \\
\text { stated; no associated volvulus }\end{array}$ & $\begin{array}{l}\text { Elective surgery; } \\
\text { laparoscopic repair; } \\
\text { primary closure; Nissen } \\
\text { fundoplication }\end{array}$ & $\begin{array}{l}\text { Discharged on POD } 2 \text {; } \\
\text { no reflux detected on } \\
\text { barium swallow at } 10 \mathrm{mth} \text {; } \\
\text { asymptomatic throughout } \\
12 \text { mth of follow-up }\end{array}$ \\
\hline & $\begin{array}{l}\text { 57, } \mathrm{M} \text {, reflux on } \\
\text { 24-hr } \mathrm{pH} \text { monitoring }\end{array}$ & $\begin{array}{l}1 \text { primary parahiatal hernia located } \\
\text { at the left crus; defect size not } \\
\text { stated; no associated volvulus }\end{array}$ & $\begin{array}{l}\text { Elective surgery; } \\
\text { laparoscopic repair; } \\
\text { primary closure; Nissen } \\
\text { fundoplication }\end{array}$ & $\begin{array}{l}\text { Similar postoperative } \\
\text { course as 68-yr-old } \\
\text { female patient; } \\
\text { asymptomatic throughout } \\
4 \text { yr of follow-up; no reflux } \\
\text { detected on barium swallow }\end{array}$ \\
\hline $\begin{array}{l}\text { Aragaki et al,(14) } 2006, \\
\text { Japan }\end{array}$ & $\begin{array}{l}70, \mathrm{~F} \text {, no mention } \\
\text { of reflux }\end{array}$ & $\begin{array}{l}1 \text { primary parahiatal hernia, } \\
\text { location not stated; defect size not } \\
\text { stated; no associated volvulus }\end{array}$ & $\begin{array}{l}\text { Elective surgery; } \\
\text { laparoscopic repair; } \\
\text { mesh closure; Toupet } \\
\text { fundoplication }\end{array}$ & $\begin{array}{l}\text { Discharged on POD } 11 \text {; no } \\
\text { other details provided }\end{array}$ \\
\hline \multirow[t]{2}{*}{$\begin{array}{l}\text { Palanivelu et al, }{ }^{(13)} \\
2008, \text { India }\end{array}$} & $\begin{array}{l}32, M ; 55, M \\
29, M ; 65, M\end{array}$ & $\begin{array}{l}\text { All } 4 \text { patients had } 1 \text { primary } \\
\text { parahiatal hernia located at the } \\
\text { left crus; mean defect size: } 18 \mathrm{~cm}^{2} \text {; } \\
1 \text { patient had volvulus }\end{array}$ & $\begin{array}{l}\text { All } 4 \text { patients had } \\
\text { elective surgery; } \\
\text { laparoscopic repair; mesh } \\
\text { closure; } 2 \text { patients had } \\
\text { fundoplication }\end{array}$ & \multirow[t]{2}{*}{$\begin{array}{l}\text { Nasogastric tubes were } \\
\text { removed from POD } 1-4 ; \\
\text { oral fluids followed by } \\
\text { solids after nasogastric } \\
\text { tube removal; mean hospital } \\
\text { stay: } 5 \text { days }\end{array}$} \\
\hline & $\begin{array}{l}45, \mathrm{~F} ; 70, \mathrm{M} ; \\
29, \mathrm{M} ; 65, \mathrm{M} ; \\
\text { reflux symptoms in } \\
3 \text { of } 4 \text { patients }\end{array}$ & $\begin{array}{l}\text { All } 4 \text { patients had } 1 \text { secondary } \\
\text { parahiatal hernia ( } 3 \text { had previous } \\
\text { fundoplication and } 1 \text { had } \\
\text { transhiatal surgery for oesophageal } \\
\text { leiomyoma); mean defect size: } 7.25 \\
\mathrm{~cm}^{2} \text {; volvulus not stated }\end{array}$ & $\begin{array}{l}\text { All } 4 \text { patients had elective } \\
\text { surgery; laparoscopic } \\
\text { repair; } 2 \text { patients had } \\
\text { mesh repair }\end{array}$ & \\
\hline $\begin{array}{l}\text { Ohtsuka et al, }{ }^{(15)} 2012 \text {, } \\
\text { Japan }\end{array}$ & $\begin{array}{l}39, \mathrm{M} \text {, no mention } \\
\text { of reflux }\end{array}$ & $\begin{array}{l}1 \text { primary parahiatal hernia located } \\
\text { at the left crus; defect size: } \\
5 \mathrm{~cm} \text { diameter; associated with } \\
\text { mesenteroaxial volvulus }\end{array}$ & $\begin{array}{l}\text { Emergency surgery; } \\
\text { laparoscopic repair; } \\
\text { primary closure }\end{array}$ & Not stated \\
\hline $\begin{array}{l}\text { Takemura et al,(12) } \\
\text { 2013, Japan }\end{array}$ & $\begin{array}{l}70, \mathrm{M} \text {, no mention } \\
\text { of reflux }\end{array}$ & $\begin{array}{l}1 \text { secondary parahiatal } \\
\text { hernia (pleural mesothelioma); } \\
\text { defect size: } 3 \mathrm{~cm} \text { diameter; } \\
\text { volvulus not stated }\end{array}$ & $\begin{array}{l}\text { Elective surgery; } \\
\text { laparoscopic repair; } \\
\text { primary closure }\end{array}$ & $\begin{array}{l}\text { Oral intake on POD } 5 \text {; } \\
\text { discharged on POD 29; no } \\
\text { other details provided }\end{array}$ \\
\hline
\end{tabular}

F: female; M: male; POD: postoperative day

In conclusion, giant PEHs and parahiatal hernias are rare conditions in the Asian context. Although most patients with either condition are asymptomatic and incidentally diagnosed, some may present emergently. A significant proportion of the patients in the present study underwent emergency surgery. Although patients who underwent emergency open surgery had good surgical outcomes, more emphasis should be directed toward early diagnosis and elective laparoscopic repair of such hernias, as laparoscopic repair may offer a faster postoperative recovery. The surgical approach to crural dissection may differ if parahiatal hernia is suspected, and this differential diagnosis should be actively excluded.

\section{REFERENCES}

1. Ronkainen J, Aro P, Storskrubb T, et al. High prevalence of gastroesophageal reflux symptoms and esophagitis with or without symptoms in the general adult Swedish population: a Kalixanda study report. Scand J Gastroenterol 2005; 40:275-85

2. Ronkainen J, Aro P, Storskrubb T, et al. Prevalence of Barrett's esophagus in the general population: an endoscopic study. Gastroenterology 2005; 129:1825-31.

3. Zagari RM, Fuccio L, Wallander MA, et al. Gastro-oesophageal reflux 
symptoms, oesophagitis and Barrett's oesophagus in the general population: the Loiano-Monghidoro study. Gut 2008; 57:1354-9.

4. Zou D, He J, Ma X, et al. Epidemiology of symptom-defined gastroesophageal reflux disease and reflux esophagitis: the systematic investigation of gastrointestinal diseases in China (SILC). Scand ) Gastroenterol 2011; 46:133-41.

5. MacArthur KE. Hernias and volvulus of the gastrointestinal tract. In: Feldman M, Scharschmidt BF, Sleisenger MH, Klein S, eds. Sleisenger \& Fordtran's gastrointestinal and liver disease. Philadelphia: WB Saunders, 1998: 318-27.

6. Aly A, Munt J, Jamieson GG, et al. Laparoscopic repair of large hiatal hernias. Br J Surg 2005; 92:648-53.

7. Skinner DB, Belsey RH. Surgical management of esophageal reflux and hiatus hernia. Long-term results with 1,030 patients. J Thorac Cardiovasc Surg 1967; 53:33-54

8. Pierre AF, Luketich JD, Fernando HC, et al. Results of laparoscopic repai of giant paraesophageal hernias: 200 consecutive patients. Ann Thorac Surg 2002; 74:1909-15; discussion 1915-6.

9. Chang $\mathrm{CC}$, Tseng $\mathrm{CL}$, Chang YC. A surgical emergency due to an incarcerated paraesophageal hernia. Am J Emerg Med 2009; 27:134.e1-3.

10. Watanabe G, Tanaka J, Odashima S, Kitamura M, Koyama K. Laparoscopic repair of a paraesophageal hiatus hernia without fundoplication. Surg Today 1997; 27:1093-6.

11. Scheidler MG, Keenan RJ, Maley RH, et al. "True" parahiatal hernia: a rare entity radiologic presentation and clinical management. Ann Thorac Surg 2002; 73:416-9.

12. Takemura M, Mayumi K, Ikebe T, Hamano G. Laparoscopic repair of secondary parahiatal hernia with incarceration of the stomach: a case report. J Med Case Rep 2013; 7:50.

13. Palanivelu C, Rangarajan M, Jategaonkar PA, Parthasarathi R, Balu K. Laparoscopic repair of parahiatal hernias with mesh: a retrospective study. Hernia 2008; 12:521-5.

14. Aragaki M, Kojima T, Hiraguchi E, et al. Laparoscopic surgery for parahiatal type of diaphragmatic hernia-report of a case. Jpn J Gastroenterol Surg 2006; 39:1577-81.

15. Ohtsuka H, Imamura K, Adachi K. An unusual diaphragmatic hernia. Parahiatal hernia. Gastroenterology 2012; 142:1420.

16. Demmy TL, Boley TM, Curtis JJ. Strangulated parahiatal hernia: not just another paraesophageal hernia. Ann Thorac Surg 1994; 58:226-7.

17. Rodefeld MD, Soper NJ. Parahiatal hernia with volvulus and incarceration: laparoscopic repair of a rare defect. J Gastrointest Surg 1998; 2:193-7.

18. Kahrilas PJ, Kim HC, Pandolfino JE. Approaches to the diagnosis and grading of hiatal hernia. Best Pract Clin Gastroenterol 2008; 22:601-16.

19. Petersen H, Johannessen T, Sandvik AK, et al. Relationship between endoscopic hiatus hernia and gastroesophageal reflux symptoms. Scand J Gastroenterol 1991; 26:921-6.

20. Goh KL, Chang CS, Fock KM, et al. Gastro-oesophageal reflux disease in
Asia. J Gastroenterol Hepatol 2000; 15:230-8.

21. Kang JY, Tay HH, Yap I, et al. Low frequency of endoscopic esophagitis in Asian patients. J Clin Gastroenterol 1993; 16:70-3.

22. Yeom JS, Park HJ, Cho JS, Lee SI, Park IS. Reflux esophagitis and its relationship of hiatal hernia. J Korean Med Sci 1999; 14:253-6.

23. Hu WHC, Hui WM, Lam CLK, Lam SK. Anxiety and depression are Cofactors determining health care utilisation in patients with dyspepsia: a Hong Kong population based study. Gastroenterology 1997; 112(Suppl):A153.

24. Chang CS, Poon SK, Lien HC, Chen GH. The incidence of reflux esophagitis among the Chinese. Am J Gastroenterol 1997; 92:668-71.

25. Kang JY, Ho KY. Different prevalences of reflux oesophagitis and hiatus hernia among dyspeptic patients in England and Singapore. Eur J Gastroenterol Hepatol 1999; 11:845-50.

26. Mahadeva S, Raman MC, Ford AC, et al. Gastro-oesophageal reflux is more prevalent in Western dyspeptics: a prospective comparison of British and South-East Asian patients with dyspepsia. Aliment Pharmacol Ther. 2005;21:1483-90

27. Stylopoulos N, Gazelle GS, Rattner DW. Paraesophageal hernias: operation or observation? Ann Surg 2002; 236:492-500; discussion 500-1.

28. Wasselle JA, Norman J. Acute gastric volvulus: pathogenesis, diagnosis, and treatment. Am J Gastroenterol 1993; 88:1780-4.

29. Iannelli A, Fabiani P, Karimdjee BS, et al. Laparoscopic repair of intrathoracic mesenterioaxial volvulus of the stomach in an adult: report of a case. Surg Today 2003; 33:761-3.

30. Katkhouda N, Mavor E, Achanta K, et al. Laparoscopic repair of chronic intrathoracic gastric volvulus. Surgery 2000; 128:784-90.

31. Teague WJ, Ackroyd R, Watson DI, Devitt PG. Changing patterns in the management of gastric volvulus over 14 years. Br J Surg 2000; 87:358-61.

32. Nason KS, Luketich JD, Witteman BPL, Levy RM. The laparoscopic approach to paraesophageal hernia repair. J Gastrointest Surg 2012; 16:417-26.

33. Casaccia M, Torelli P, Panaro F, et al. Laparoscopic physiological hiatoplasty for hiatal hernia: new composite " $\mathrm{A}$ "-shaped mesh. Physical and geometrical analysis and preliminary clinical results. Surg Endosc 2002; 16:1441-5.

34. Stadlhuber RJ, Sherif AE, Mittal SK, et al. Mesh complications after prosthetic reinforcement of hiatal closure: a 28-case series. Surg Endosc 2009; 23:1219-26

35. Granderath FA, Carlson MA, Champion JK, et al. Prosthetic closure of the esophageal hiatus in large hiatal hernia repair and laparoscopic antireflux surgery. Surg Endosc 2006; 20:367-79.

36. Hashemi M, Peters JH, DeMeester TR, et al. Laparoscopic repair of large type III hiatal hernia: objective followup reveals high recurrence rate. J Am Coll Surg 2000; 190:553-60; discussion 560-1.

37. Mattar SG, Bowers SP, Galloway KD, Hunter JG, Smith CD. Long-term outcome of laparoscopic repair of paraesophageal hernia. Surg Endosc $2002 ; 16: 745-9$ 